\title{
Newly developed TGF- $\beta 2$ knock down transgenic mouse lines express TGF- $\beta 2$ differently and its distribution in multiple tissues varies
}

\author{
Yan-Bin XiYang ${ }^{1}$, Fang Wang ${ }^{1}$, Bao-Jiang Qian ${ }^{1}$, Ling You' ${ }^{1}$ Bing-Tuan Lu' ${ }^{1}$ Wei Zhang ${ }^{3}$, Xiong-Zhi Quan³ \\ Wen-Ping Ge ${ }^{3}$, Su Liu', Lian-Feng Zhang ${ }^{3,4^{*}}$ and Ting-Hua Wang ${ }^{1,2^{*}}$
}

\begin{abstract}
Background: Transforming growth factor-betas (TGF- $\beta$ s), including beta2 (TGF- $\beta 2$ ), constitute a superfamily of multifunctional cytokines with important implications in morphogenesis, cell differentiation and tissue remodeling. TGF- $\beta 2$ is thought to play important roles in multiple developmental processes and neuron survival. However, before we carried out these investigations, a TGF- $\beta 2$ gene down-regulated transgenic animal model was needed. In the present study, expressional silencing TGF- $\beta 2$ was achieved by select predesigning interference short hairpin RNAs (shRNAs) targeting mouse TGF- $\beta 2$ genes.

Results: Four homozygous transgenic offspring were generated by genetic manipulation and the protein expressions of TGF- $\beta 2$ were detected in different tissues of these mice. The transgenic mice were designated as Founder 66, Founder 16, Founder 53 and Founder 41. The rates of TGF- $\beta 2$ down-expression in different transgenic mice were evaluated. The present study showed that different TGF- $\beta 2$ expressions were detected in multiple tissues and protein levels of TGF- $\beta 2$ decreased at different rates relative to that of wild type mice. The expressions of TGF$\beta 2$ proteins in transgenic mice (Founder 66 ) reduced most by $52 \%$.
\end{abstract}

Conclusions: The present study generated transgenic mice with TGF- $\beta 2$ down-regulated, which established mice model for systemic exploring the possible roles of TGF- $\beta 2$ in vivo in different pathology conditions.

Keywords: TGF- $\beta 2$, Knock down, Transgenic mouse, Protein levels, Distributions

\section{Background}

Spinal cord injury (SCI) is a common medical problem, which can trigger a cascade of events, including infiltration by macrophages, activation of resident glial cells, formation of cavities in the injury site, axonal demyelination, loss of both sensory and motor neuron function and neuronal damage and death $[1,2]$.

While numerous therapeutic interventions had been attempted in the past, a lack of suitable growth

\footnotetext{
*Correspondence: lianfeng_zhang3@yahoo.com.cn; tinghua_neuron@263.net ${ }^{3}$ Key Laboratory of Human Diseases Comparative Medicine, Ministry of Health, Chinese Academy of Medical Sciences (CAMS) \& Comparative Medicine Centre, Peking Union Medical College (PUMC), NO. 5 Panjiayuan Nanli, Beijing 100021, China

'Institute of Neuroscience, Kunming Medical University, 1168 West Chunrong Road, Yuhua Avenue, Chenggong District, Kunming 650500, Yunnan, China Full list of author information is available at the end of the article
}

substrates, an insufficient activation of neuron-intrinsic regenerative programs, and extracellular inhibitors of regeneration limit the efficacy for anatomical and functional recovery after spinal cord injury [3]. The bulk of evidence has shown that the administration of some exogenous growth factors is potentially able to effect functional repair or nerveregeneration in injured spinal cords [4-6].

A large number of different cytokines/growth factors are secreted into spinal wounds by blood cells, platelets and endogenous cells. One superfamily of cytokines includes transforming growth factor- $\beta$ s (TGF $\beta \mathrm{s}$ ) [7], of which three isoforms, TGF- $\beta 1,-\beta 2$, and $-\beta 3$, have been isolated in mammals [8]. It has been generally accepted that functions of TGF- $\beta$ family members may vary depending on cellular status and cell types. TGF- $\beta$ 
isoforms have been implicated in a broad diversity of biological activities, including cell growth, cell death, cell differentiation, inflammation, and immunological reactions, by modifying the expression of specific sets of target genes [9-11]. TGF- $\beta$ has been shown to be both pro- and anti- apoptotic, influenced by both context and location. Increases or decreases in the production of TGF- $\beta$ have been linked to numerous disease states, including atherosclerosis and fibrotic disease of the kidney, optical nerve, liver and lung. TGF- $\beta$, especially TGF- $\beta 2$, is the predominant cytokine that plays an important role in the development of fibrosis [12-15]. Reports demonstrated that the later induction of TGF$\beta 2$ at the point of SCI may indicate a role in the maintenance of the scar [16]. It therefore suggested TGF- $\beta 2$ is possibly involved in neuroplasticity following SCI. However, newly developed TGF- $\beta 2$ knock down transgenic mouse lines express TGF- $\beta 2$ is still needed.

In the present study, we established transgenic ( $\mathrm{Tg}$ ) mice with TGF- $\beta 2$ knock down by genetic manipulation. Polymers chain reaction (PCR) was performed to identify the genotypes of mice. Then, Western blot and immunohistochemistry (IHC) were employed to detect the protein expressional levels and distributions of TGF- $\beta 2$ in multiple tissues of different genotypes Tg mice. These tissues were olfactory bulb, cortex, frontal lobe, basal forebrain, cerebellum, hypothalamus, medulla oblongata, spinal cord, trachea, lung, heart, liver, spleen, kidney, adrenal gland, intestines, skeletal muscles and epidermis. The rates of TGF- $\beta 2$ down-regulation in multiple tissues of different genotypes were evaluated by relative intensity to the level of wild type (WT).

\section{Results}

\section{Genotypes detection of TG}

Five heterozygosis transgenic offspring of TGF- $\beta 2-k d$ lines were obtained. Four of them could generate offspring, which were designated as Founder 66, Founder 16, Founder 53 and Founder 41. The $\mathrm{Tg}$ mice with inserted fragment, identified by PCR, were regarded as positive Tg (Figure 1).

\section{Protein expressional changes of TGF- $\beta 2$ in multiple tissues of TG with different genotype}

Results of Western blot, which detected in different multiple tissues of four genotypes TG (Founder 66, Founder 16, Founder 53 and Founder 41), indicated that TGF- 32 expressions were down-regulated by different percentages in the four kinds of TG mice (Figures 2 and 3 ). The rates of protein down-regulation were calculated as following: Rates of protein downregulation $=$ O.D. of WT- O.D. of Founder/O.D. of WT *100\%. (O.D.: optical density).

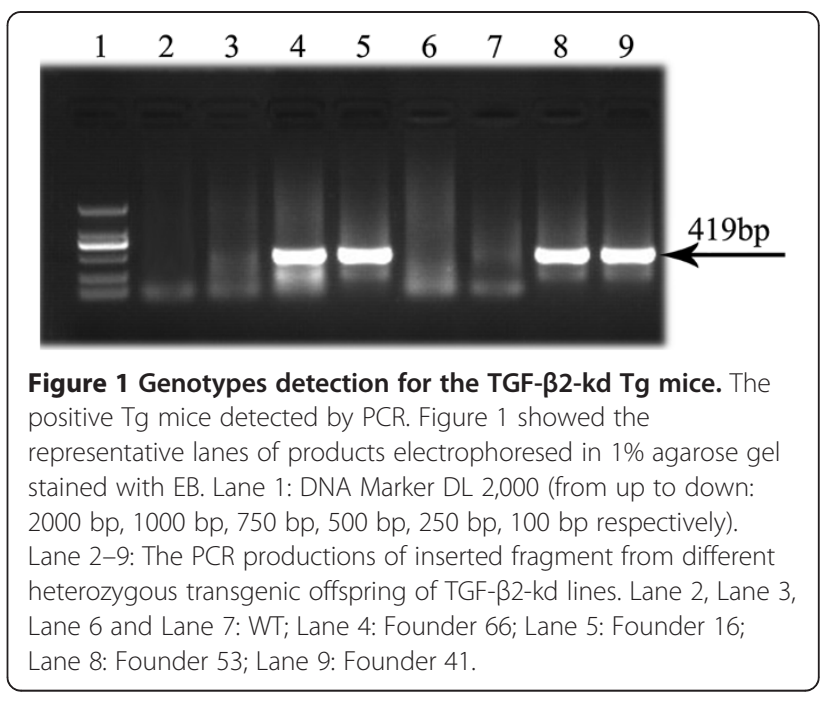

\section{Distributions of TGF- $\beta 2$ in multiple tissues}

Control of immunostaining specificity was performed by replacing the primary antibody with $2 \%$ goat serum. These controls did not exhibit any specific immunestaining in the olfactory bulb and brain (Figure $4 S$ and $\mathrm{T}$, respectively).

\section{Olfactory bulb}

Immunoreactions (IR) of TGF- $\beta 2$ was seen in basal cells, supporting cells, neurons, apical cytoplasmic region of olfactory epithelium, lamina propria and gland's cell cytoplasm. Positive-reactions were seen in a majority in the cytoplasm (Figure 4A).

\section{Brain}

The distributions of TGF- $\beta 2$ immunopositive neurons and glia-liked cells were observed within the cortex, basal brain, frontal lobe, cerebellum, hypothalamus and medulla oblongata. They occurred in all layers of the cortical regions examined in this study, including the external and internal pyramidal layers. The somata and proximal dendrites with TGF- $\beta 2$ IR were observed in the brain stem. A stronger labeling was present in granular cells and in axon-like fibers of the molecular cell layer. A few scattered immunopositive neuronal cell bodies and processes were present in the fastigial and dentate nucleus. Immunoreaction products of TGF- $\beta 2$ were mainly observed in the cytoplasm and perikarya of these neurons. Nuclei of these cells were not stained (Figure 4B-D).

\section{Spinal cord}

TGF- $\beta 2$ immunopositive profiles were present in rostral horn, ventral horn neurons as well as white matter of the spinal cord. The IR could be seen in the cytoplasm and processes, but not in the nucleus (Figure 4E-G). 

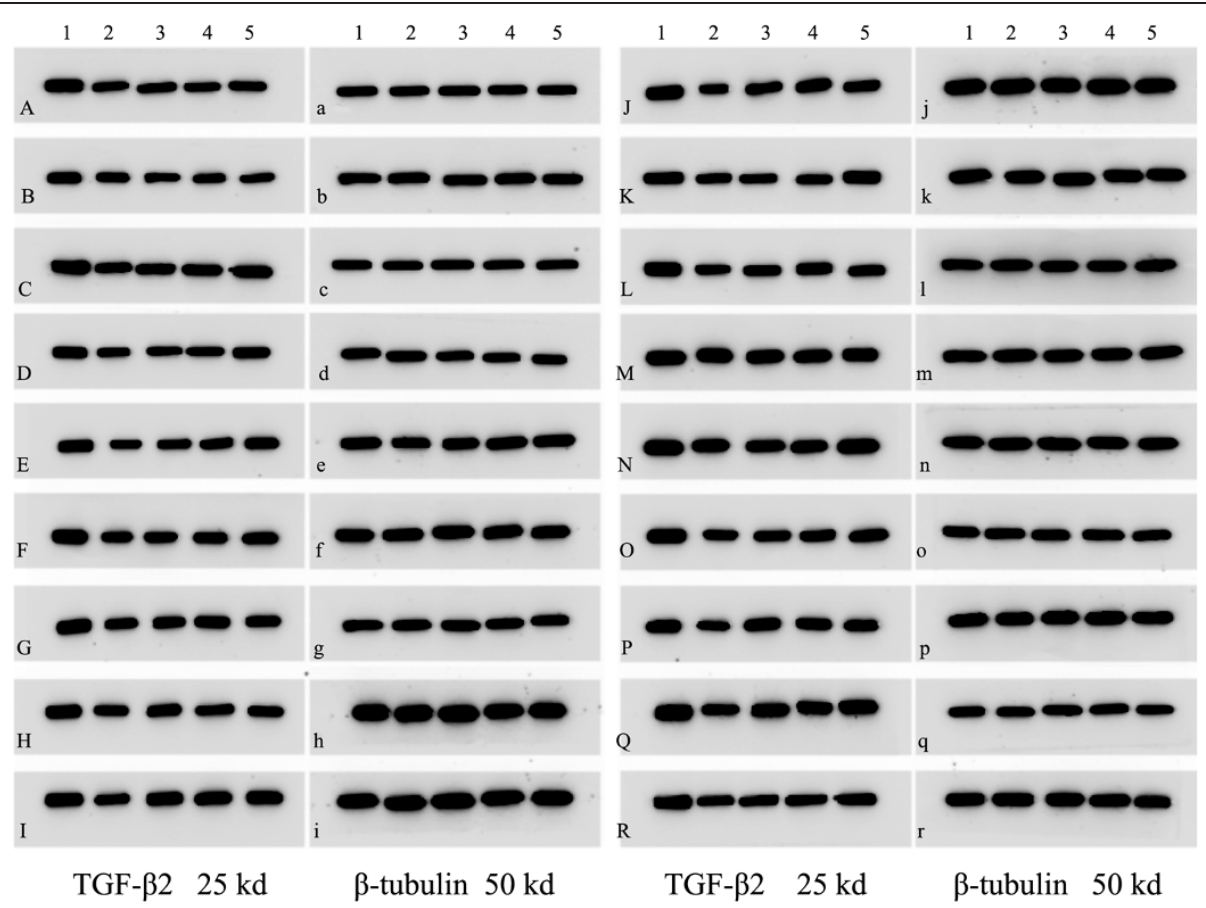

Figure 2 Protein expressions of TGF- $\beta 2$ detected by WB in different tissues. Figure 2 Lane 1-5, TGF- $\beta 2$ protein expression; Lane 1, WT; Lane 2, Founder 66; Lane 3, Founder 16; Lane 4, Founder 53; Lane 5, Founder 41. A, a: olfactory bulb; B, b: cortex; C, c: frontal lobe; D, d: basal forebrain; E, e: cerebellum; F, f: hypothalamus; G, $\mathbf{g}$ : medulla oblongata; $\mathbf{H}, \mathbf{h}$ : spinal cord; I, i: trachea; J, j: lung; K, k: heart; L, I: liver; $\mathbf{M}, \mathbf{m}$ : spleen; $\mathbf{N}$, n: kidney; O, o: adrenal gland; P, p: intestines; Q, q: skeletal muscles; $\mathbf{R}, \mathbf{r}$ : epidermis. Beta-tubulin was chased as the control.

\section{Lung}

TGF- $\beta 2$ immunopositive profiles were found in the epithelial cells, vascular endothelial cells, as well as white blood cells. The IR was seen in the cytoplasm but not in the nuclei (Figure $4 \mathrm{H}$ ).

\section{Liver}

TGF- $\beta 2$ was distributed in the cytoplasm of hepatocytes throughout the liver lobule. The IR of TGF- $\beta 2$ was partially seen in liver acinus (Figure 4K).

\section{Spleen}

IR of TGF- $\beta 2$ was detected in Tunica media of artery, subendothelial smooth muscle cell and endotheliocyte. The immunoreactions then were seen in cytoplasm, but not in nucleus (Figure 4L).

\section{Kidney}

Representative IR for TGF- $\beta 2$ in renal section of $\mathrm{Tg}$ mice showed diffuse positive staining within renal cortex, medullary interstitial, as well as the epithelial cells of the proximal convoluted tubule (Figure 4M).

\section{Adrenal gland}

The majority of TGF- $\beta 2$ positive cells are located directly underneath the capsule, in the adrenal cortex (Figure 4N).

\section{Intestine}

TGF- 32 immunopositive files dispersed in lamina propria, epithelium mucosae and muscular layer. The immunepositive staining was primarily in the cytoplasm and partial cytolemma (Figure 4O).

\section{Muscle}

TGF- $\beta 2$ staining was localized to the sarcolemma in skeletal muscle of mice. In the sarcoplasm there was staining in a transverse striation pattern at regular intervals the length of a sarcomere (Figure 4P and Q). Immunostaining for TGF- $\beta 2$ also showed positive staining in coronary arteries of hearts (Figure 4I and J).

\section{Epidermis}

The positive-reactions of TGF- $\beta 2$ were detected in the epidermis of TG mice. The IR was found in cytoplasm and cytolemma of basal cells and follicular epithelium (Figure 4R).

\section{Discussion}

The present study generated different expression levels of TGF- $\beta 2$ transgenic mice, which demonstrated that delivering shRNAs targeting TGF- 32 gene could induce TGF- $\beta 2$ protein expression decrease in transgenic mice, especially in the central nervous system. Also, the expressed decrease in TGF- $\beta 2$ protein was diverse in 


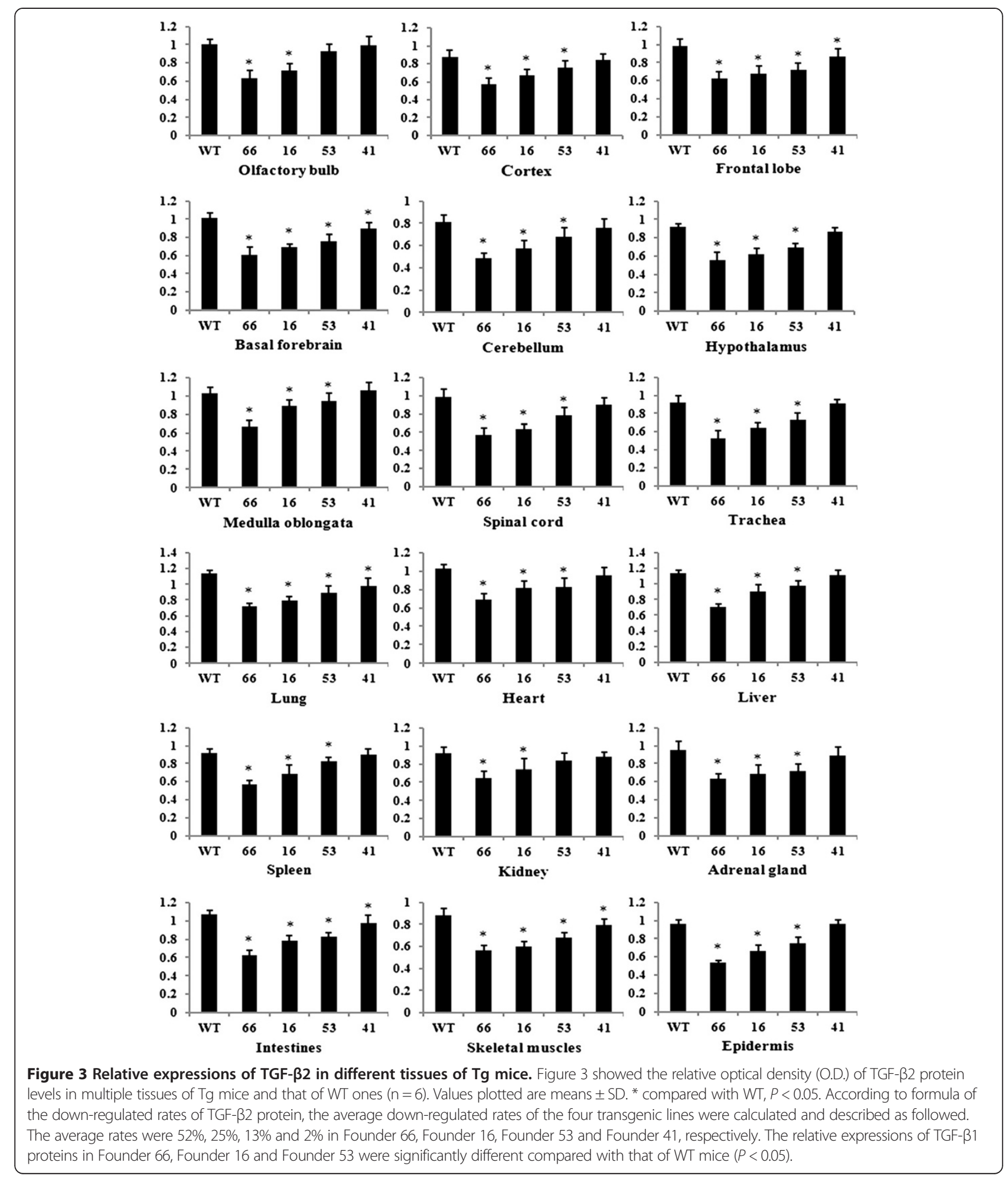

different phenotypic transgenic lines. The results detected by Western blot analysis showed that the lowest value $(52 \%)$ of TGF- $\beta 2$ protein was detected in Founder 66, while it was only $2 \%$ in Founder 41 . In addition, we explored the systemic distribution of TGF- $\beta 2$ in various tissues of TG mice, including the olfactory bulb, basal forebrain, cerebellum, cortex, hypothalamus, frontal lobe, medulla oblongata, spinal cord, lung, heart, liver, spleen, kidney, adrenal gland, intestines, skeletal muscles and epidermis. Newly developed Tg mice 


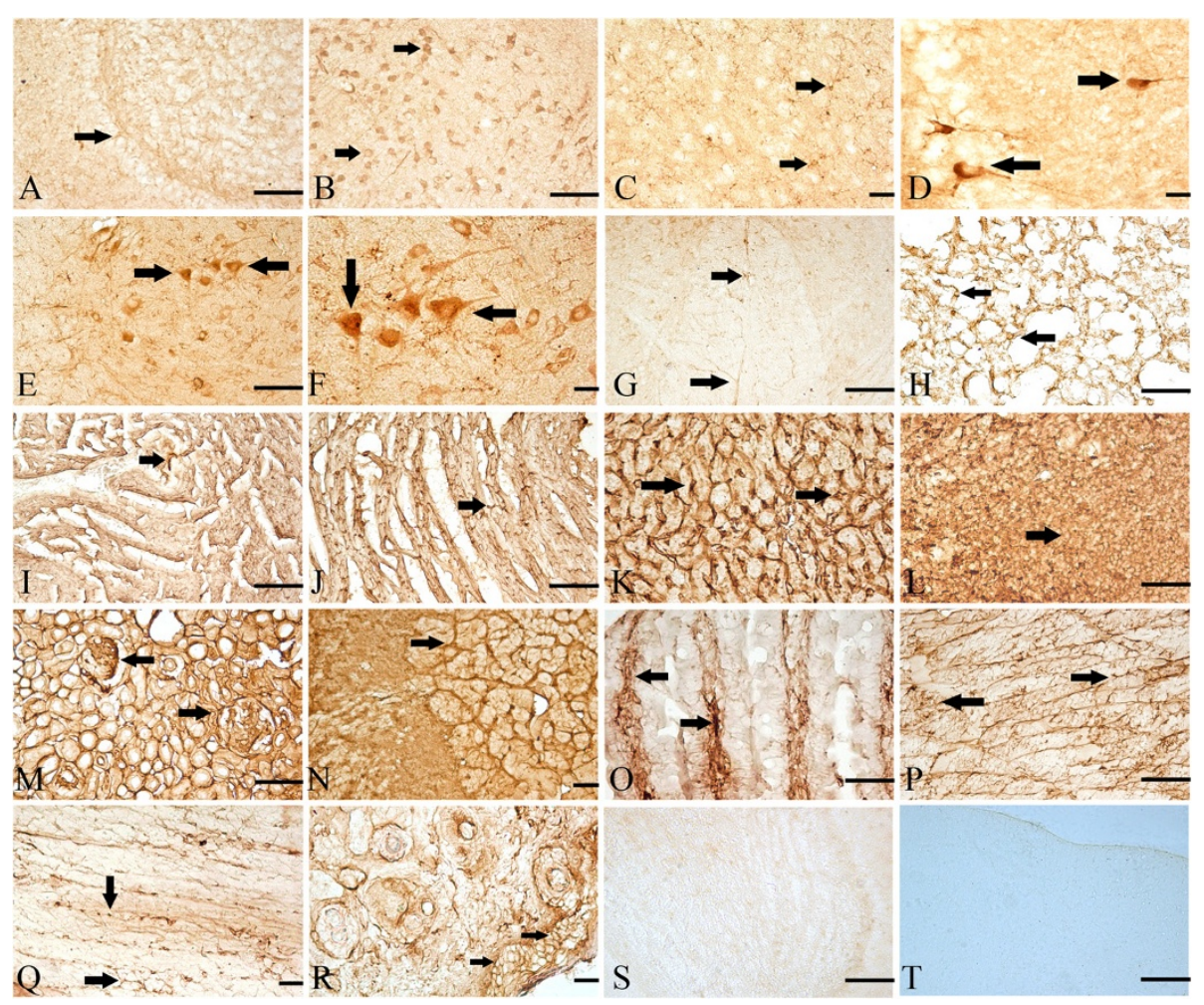

Figure 4 Locations of TGF- $\beta 2$ in multiply tissues of Tg mice. The arrow showed the representative IR of TGF- $\beta 2$ in Founder 66 . A: olfactory bulb (arrow showed supporting cell); B: cortex frontal lobe (arrows showed neuron); C: basal forebrain (arrows showed neuron); D: hypothalamus (arrows showed neuron); E, F and G: spinal cord (arrows showed, E and F: motor neurons in the ventral horn); G: astrocyte-like cells in whiter matter); H: lung (arrows showed the lung epithelial cell); I and J: heart (arrows showed the sarcolemma); K: liver (arrows showed); L: spleen (arrow showed subendothelial smooth muscle cell); M: kidney (arrows showed epithelial cells); N: adrenal gland; O: intestines (arrows showed the staining lamina); $\mathbf{P}$ and $\mathbf{Q}$ : skeletal muscles (arrows showed the staining sarcolemma); R: epidermis (arrows showed the basal cells); $\mathbf{S}$ : control of olfactory bulb; T: control of brain. Magnifications: C, D, N, Q and R: 400x; other: 200x; Scale bar: $10 \mu \mathrm{m}$.

models of TGF- $\beta 2$ down-regulation could be useful to further investigations.

Our results of PCR for genotypes detection, which showed that the inserted fragments (419 bp) were detected in four Tg offspring of TGF- $\beta 2-k d$ lines, indicated that new $\mathrm{Tg}$ mice model of TGF- $\beta 2-\mathrm{kd}$ lines were obtained successfully by genetic manipulation. This study generated four kinds of available $\mathrm{Tg}$ mice, which were designated Founder 66, Founder 16, Founder 53 and Founder 41 . These data strongly suggest that silence shRNAs for TGF- $\beta 2$ can be used for the creation of a continuous mammalian model in which selected target genes are stably suppressed and attenuated in vivo.

RNA interference (RNAi) is an extremely effective tool for studying gene function in almost all metazoan and eukaryotic model systems. RNAi in mice, through the expression of short hairpin RNAs (shRNAs), offers something not easily achieved with traditional genetic approaches-inducible and reversible gene silencing. Previous research undertook targeted disruption of the
TGF- $\beta 2$ gene to determine its essential role in vivo. They demonstrated that TGF- $\beta 2$-null mice exhibited perinatal mortality and a wide range of developmental defects for a single gene disruption. These include cardiac, lung, craniofacial, limb, spinal column, eye, inner ear and urogenital defects [17]. The present results show that shRNAs-TGF- $\beta 2$ can induce extensive TGF- $\beta 2$ downregulation in mice. A random integration of a transgenic fragment effectively reduced the systemic expressions of TGF- $\beta 2$ in $\mathrm{Tg}$ mice. However, the expression of decreased TGF- $\beta 2$ protein was varied in different phenotypic lines, such that the highest rates of TGF- $\beta 2$ downexpression (52\%) was detected in Founder 66, while that of Founder 41 was only decreased by $2 \%$. The diverse expression of TGF- $\beta 2$ protein in four kinds of $\mathrm{Tg}$ mice might have been due to the randomness of insertion sites of the recombination vectors in the target gene. Furthermore, some unknown mechanisms of posttranscription regulation in different tissues might induce the different levels of TGF- $\beta 2$ expressions in multiple 
tissues. Epigenetic deregulation of the TGF- $\beta 2$ gene pathway members is likely to be an early event in breast cancer formation, which was resulted from the epigenetic regulation (such as histone methylation and deacetylation rather than DNA methylation) of TGF- $\beta 2$ in a gene pathway [18]. In normal adult animals, TGF- $\beta$ s (1-3) are ubiquitously and abundantly expressed in neurons and glia cells in both CNS and PNS [19-23]. The three TGF-beta isoforms described in mammals (TGF- $\beta 2$, TGF- $\beta 2$ and TGF- $\beta 3$ ) have prominent functions related to morphogenetic events, epithelial-mesenchymal interactions, and differentiation $[24,25]$. A number of studies have suggested that TGFbeta1, 2, and 3 have differential temporal effects during the wound-healing process, and are important for optimal wound healing in the first week after wounding; beyond 1 week, TGF-beta1, 2, and 3 play a critical role in hypertrophic scar formation [26]. Furthermore, knockout mice have revealed their importance in regulating inflammation and tissue repair [27,28].

However, there is no report about newly developed TGF- $\beta 2$ knock down transgenic mouse lines and the systemic distributions of TGF- $\beta 2$ in Tg mice. The surveys of TGF- $\beta 2$ distributions in newly developed TGF- $\beta 2$ knock down transgenic mouse lines provided some crucial information to investigate the role of TGF- $\beta 2$ under physiological and pathological condition.

In summary, this study developed $\mathrm{Tg}$ mice lines with TGF- $\beta 2$ down-regulation and the systemic morphologic information that can be used in further research. Our results showed that TGF- $\beta 2$ proteins were widespread in multiple tissues, especially in nervous systems, intestines and epidermis. These results indicated that TGF- $\beta 2$ might play multiple different biologic roles according to the different cell types. Moreover, the present results generated four genotypes TGF- $\beta 2 \mathrm{Tg}$ mice of expressional down-regulated by different folds, which supplied multiple genotypes Tg mice sources for different research.

\section{Conclusion}

Our study established new transgenic mice lines with extensive down-regulation of TGF- $\beta 2$. We also supplied the down-regulated rates and systemic distributions of TGF- $\beta 2$ protein in four phenotypic transgenic mice. The results showed that TGF- $\beta 2$ knockdown mice like Founder 66 could be designated as the target lines for further research.

\section{Methods}

\section{Animal generation}

Animal use and care were in accordance with the animal care guidelines, which conformed to the Guide for the Care and Use of Laboratory Animals published by the US National Institutes of Health (NIH Publication No. 85-23, revised 1996).
TGF- $\beta 2$ knock down (TGF- $\beta 2-k d)$ transgenic (Tg) mice with C57BL/6J genetic background were produced by our collaborators in The Institute of Laboratory Animal Science (Chinese Academy of Medical Sciences \& Comparative Medicine Centre, Peking Union Medical College, Beijing, China). The generation of the transgenic mice was described as follows. Briefly, at least three silence expression sites of TGF- $\beta 2$ were designed by software supplied by Invitrogen Company, USA. Then we selected predesigned short hairpin RNA (shRNAs) that target mouse TGF- $\beta 2$ gene (Mus musculus, GeneID: 21808). The reconstruction plasmid was designed (Figure 5A) and purchased from Invitrogen Company. The constructed recombinant plasmid was transferred into $293 \mathrm{~T}$ cells. The transformants were screened and identified by polymers chain reaction (PCR) detections and restriction analysis (Figure 5B, C and D).

The protocol of PCR is described as follows. The transgene was then isolated from the cloning plasmid and purified by Avr II digestion, followed by diluted to a final concentration of $5 \mathrm{ng} / \mu \mathrm{L}$. The final transgenic fragment was microinjected into fertilized mouse eggs $(\mathrm{F} 1[\mathrm{C} 57 \mathrm{BL} / 6 \times \mathrm{CBA} / \mathrm{J}] \times \mathrm{F} 1[\mathrm{C} 57 \mathrm{BL} / 6 \times \mathrm{CBA} / \mathrm{J}])$. Detection for the transgenic fragment is described as follows.

Transgenic mice were mated with nontransgenic partners to maintain heterozygozity of the transgene or with transgenic partners to generate homozygous transgenic offspring. In the latter case, transgenic male mice were test mated with two wild-type female mice, and the offspring (15-20 individuals) was analyzed by polymerase chain reaction (PCR). Male mice that produced exclusively transgenic offspring were considered homozygous for the transgene. TGF- $\beta 2-\mathrm{kd} \mathrm{Tg}$ mice and their age-matched, non-transgenic littermates (wild type mice) were used.

\section{Real-time polymers chain reaction (RT-PCR)}

The effects of shRNA target to TGF- $\beta 2$ gene were detected by RT-PCR in transferred 293T cells. Total RNA was isolated from the harvested cells by using Trizol reagent (Invitrogen). cDNA was synthesized by using Oligo (dT) 18 and MMLV reverse transcriptase (Promega, Madison, WI). Primers employed were synthesized by Takara (Takara, Japan) and are described as follows. For detections in expression of TGF- $\beta 2$ mRNA, the following primers were used: sense, 5' CGGAGCATGGAAGTCACAG 3'; antisense, 5' ACCACAGCCAGGAAACCC 3'. For GAPDH detections, the following primers were used: sense, $5^{\prime}$ CAAGGTCATCCATGACAACTTTG 3'; anti-sense, 5' GTCCACCACCCTGTTGCTGTAG 3'. The cDNA was 10 -fold serially diluted to seven concentrations for the standard curve. 

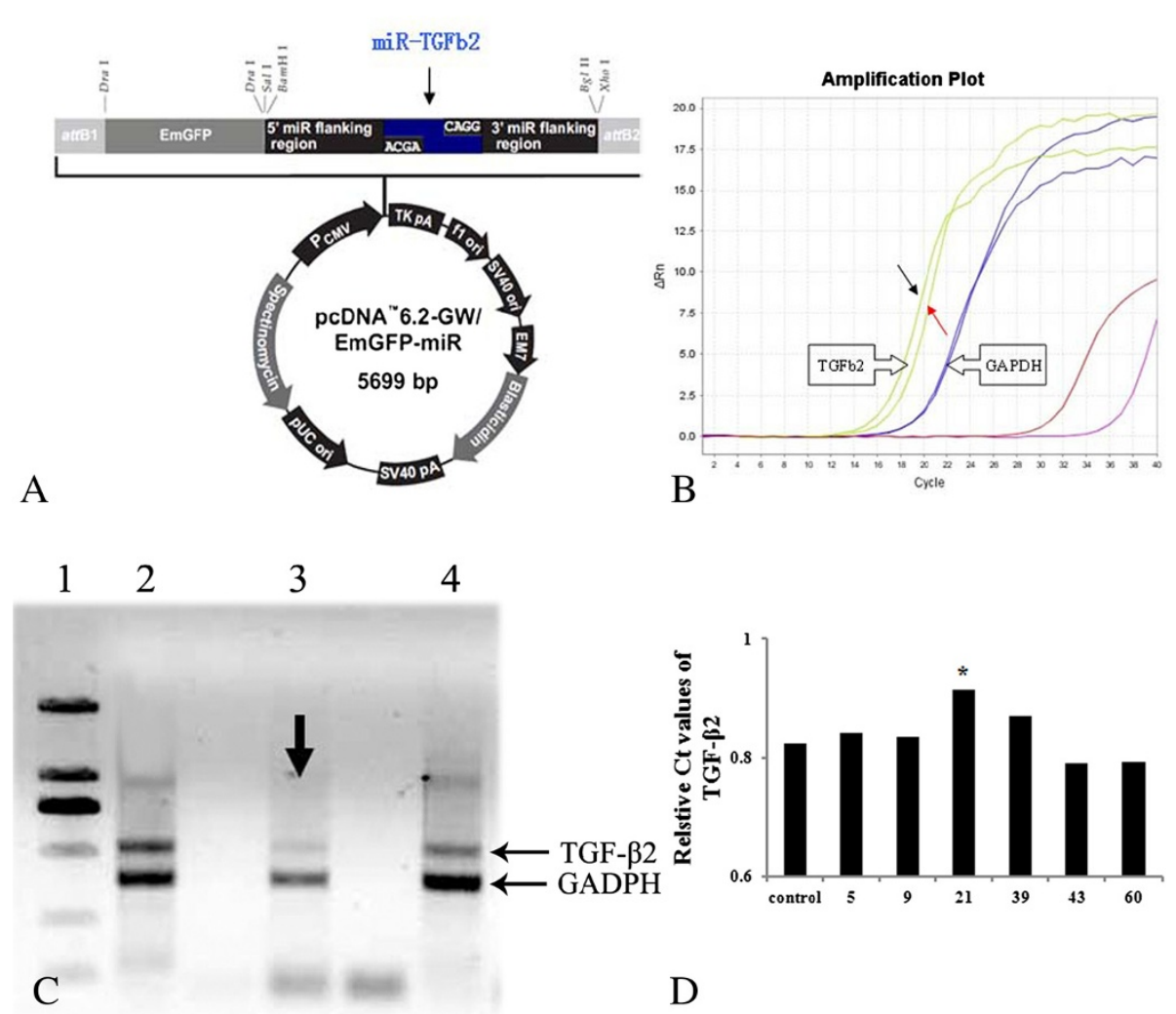

Figure 5 Recombination plasmid for Tg mice with TGF- $\beta 2$ down-regulation. A: showed the schedules of recombination plasmid for pcDNA6.2-GW/EmGFP-miR of TGF- $\beta 2$ gene silence, which composed with 5699 nucleotides. The 293T cells were transfected with the transgenic vectors (pcDNA3.1 (+) of pcDNA6.2-GW/EmGFP-miR-TGF- $\beta 1$ ). RT-PCR was employed to evaluate the effects of PDGF-BB down-regulation transformants. B: showed the amplification plot of RT-PCR. Red arrows showed the selected cell lines as they had the lowest levels. Black arrow indicated the control ones. C: shows the represented bands of semi-quantity PCR products electrophoresed in 1\% agarose gel stained with EB. Lane 1: DL2000 DNA Marker (from up to down: 2000 bp, 1000 bp, 750 bp, 500 bp, 250 bp, 100 bp respectively); Lane 2-4: 293T cells transfected with silence expression vector for TGF- $\beta 2$ gene (lane 3: NO.21). Arrows in Figure 5 C revealed the target transformants (NO.21) for TGF- $\beta 2$ expressional silence as they had the lowest levels.

RT-PCR protocol was applied using an ABI 5700 instrument (Bio-Rad). Reactions were performed in a $20 \mu \mathrm{l}$ volume with $0.25 \mu \mathrm{M}$ primers, $5 \mathrm{mM} \mathrm{MgCl}_{2}$, nucleotides, Taq DNA polymerase, and buffers were included in the DNA Master SYBR Green I mix (Applied Biosystems). Specificity of amplification products was confirmed by melting curve analysis. PCR was performed by the denaturation step at $95^{\circ} \mathrm{C}$ for $3 \mathrm{mi}-$ nutes, followed by 35 cycles of $95^{\circ} \mathrm{C}$ for 10 seconds, $55^{\circ} \mathrm{C}$ for 10 seconds, and $72^{\circ} \mathrm{C}$ for 30 seconds. Fluorescent signals from PCR products were recorded at $85.5^{\circ} \mathrm{C}$ for 5 seconds. TGF- $\beta 2$ mRNA levels were normalized as the ratio of the fluorescence intensity from TGF- $\beta 2$ to that of GAPDH.

\section{Semi-quantity PCR}

Semi-quantity PCR analysis for the TGF- $\beta 2$ expressions in transformants was performed. Prepare for RNA samples were described as above. Then the total RNA was eluted in $20 \mu \mathrm{l}$ RNase-free Water (Gibco Life
Technologies, Rockville, MD). The RNA was kept on ice and their concentrations were measured by a Nanodrop spectrophotometer (ND-1000). An equal amount of RNA $(4 \mu \mathrm{g})$ was used for each experiment. The following primers were used: sense, 5' CGGAGCATGGAAGTCACAG 3'; anti-sense, 5' ACCACAGCCAGGAAACCC 3'. The product length of PCR is 512 bp. For GAPDH detections, the following primers were used: sense, $5^{\prime}$ CAAGGTCATCCATGACAACTTTG 3'; anti-sense, 5' GTCCACCACCCTGTTGC- TGTAG 3'. The product length of PCR is $457 \mathrm{bp}$. Gene primers were synthesized by TaKaRa Company.

Experiments were duplicated to verify the results. For RNA amplification, the first-strand cDNA was synthesized from $4 \mu \mathrm{g}$ of total RNA, using Revert AidTM First Strand cDNA Synthesis Kit (Fermentas Company, U.S.A.). PCR was then carried out using the PCR Master Mix Kit (Fermentas Company, U.S.A.) for 35 cycles, consisting of denaturation at $94^{\circ} \mathrm{C}$ for $1 \mathrm{~min}$, annealing for $1 \mathrm{~min}$, and extension at $72^{\circ} \mathrm{C}$ for $1 \mathrm{~min}$. Then PCR products 
were electrophoresed in 1\% agarose gel stained with ethidium bromide and visualized, using an ultra violet gel imager (BIO-GEL, BIP-RAD). The image analysis was performed by SYN Gene Tool (LIVE Science, U.S.A.).

\section{Assessment of genotypes}

The inserted fragment was identified by PCR. For TGF$\beta 2$-kd lines, the following primers were used: sense, 5'GAGCAAAGACCCCAACGAG 3'; antisense, 5'TTA TGA- ACAAACGACCCAACAC 3'. The lengths of PCR product is $419 \mathrm{bp}$. Briefly, PCR was carried out using the PCR Master Mix Kit (Fermentas Company, U.S.A.) for 35 cycles, consisting of denaturation at $94^{\circ} \mathrm{C}$ for 30 seconds, annealing at $60^{\circ} \mathrm{C}$ for 30 seconds, and extension at $72^{\circ} \mathrm{C}$ for 30 seconds. Then RT-PCR products were electrophoresed in $1 \%$ agarose gel stained with ethidium bromide and visualized, using an ultra violet gel imager (BIO-GEL, BIP-RAD). The image analysis was performed by SYN Gene Tool (LIVE Science, U.S.A.).

\section{Expressions of TGF- $\beta 2$ Protein in different TG mouse}

To investigate the level of TGF- $\beta 2$ protein, multiple tissues including the olfactory bulb, cortex, frontal lobe, basal forebrain, cerebellum, hypothalamus, medulla oblongata, spinal cord, trachea, lung, heart, liver, spleen, kidney, adrenal gland, intestines, skeletal muscles and epidermis were obtained from mice with different genic genotypes. After carefully rinsing in cooled PBS, the hippocampus from each was homogenized on ice in a Lysis Buffer containing 0.05 M Tris- $\mathrm{HCl}$ (pH 7.4, Amresco), 0.5 M EDTA (Amresco), 30\% TritonX-100 (Amresco), $\mathrm{NaCl}$ (Amresco), 10\% SDS (Sigma) and $1 \mathrm{mM}$ PMSF (Amresco), and centrifuged at 12,000rp for $30 \mathrm{~min}$. The supernatant was then obtained and stored at $-80^{\circ} \mathrm{C}$ for later use. Protein concentration was assayed with BCA reagent (Sigma, St. Louis, MO, USA). A $20 \mu \mathrm{l}$ aliquot of the samples was loaded on to each lane and electrophoresed on 12\% SDS-polyacrylamide gel (SDSPAGE) for $2.5 \mathrm{~h}$ at a constant voltage of $120 \mathrm{~V}$. Proteins were transferred from the gel to a nitrocellulose membrane for $6.5 \mathrm{~h}$ at $24 \mathrm{~V}$. The membrane was blocked with phosphate-buffered saline containing $0.05 \%$ Tween20 (PBST) with $10 \%$ nonfat dry milk overnight at $4{ }^{\circ} \mathrm{C}$ for $12 \mathrm{~h}$, then the membrane was washed three times for 10 min each time. They were then rinsed with PBST and incubated with the primary antibody for TGF- $\beta 2$ (1:1000, Chemican) at $4^{\circ} \mathrm{C}$ for $24 \mathrm{~h}$. After washing 3 times for 10 min each, the membrane was incubated with a HRPconjugated goat anti-rabbit IgG (1:5,000; Vector Laboratories, CA) for $2 \mathrm{~h}$ at room temperature, and washing as described above. The membrane was developed in ECM kit, and then pictured by Bio-Gel Imagining system equipped with Genius synaptic gene tool software.
Densitometry analysis for TGF- $\beta 2$ protein was performed. $\beta$-tubulin (1:500, Santa cruz) was used as internal control.

IHC

After anesthesia with $3.6 \%$ chloral hydrate $(1 \mathrm{ml} / 100 \mathrm{~g})$, mice were perfused with $150 \mathrm{ml}$ of cold phosphatebuffered saline (PBS) for $5 \mathrm{~min}$ followed by $150 \mathrm{ml}$ of 4\% paraformaldehyde solution for $30 \mathrm{~min}$. Multiple tissues described as above from each group was harvested, postfixed for 6-12 $\mathrm{h}$, then immersed in $0.1 \mathrm{M}$ PBS containing $20 \%$ sucrose overnight till the specimen sank to the bottom of the bottle. Sections of $20 \mu \mathrm{m}$ thickness were cut in a freezing microtome (Leica CM1900, Germany), collected in a plate of 24 wells, rinsed with $0.01 \mathrm{M}$ PBS three times, each for $5 \mathrm{~min}$ and soaked in PBS containing $3 \% \quad \mathrm{H}_{2} \mathrm{O}_{2}$ for $30 \mathrm{~min}$ at room temperature to block the endogenous peroxidase activity. After immersing in $0.01 \mathrm{M} \mathrm{PBS}$ containing $5 \%$ goat serum and $0.3 \%$ TritonX-100 solution at $37^{\circ} \mathrm{C}$ for $30 \mathrm{~min}$, they were subsequently incubated at $4^{\circ} \mathrm{C}$ overnight with $2 \%$ goat serum containing goat polyclonal antibodies TGF- $\beta 2$ (1:800, Santa Cruz). They were washed three times (5 min each time) in $0.01 \mathrm{M} \mathrm{PBS}$ containing $0.1 \%$ Tween-20 (PBST), and incubated in Reagents I and II from the PV-9000 Reagent Kit (Chemicon, Anti-Rabbit/Mouse Poly-HRP IHC Detection Kit, USA), each for $30 \mathrm{~min}$ at $37^{\circ} \mathrm{C}$. It was again rinsed five times, each for $5 \mathrm{~min}$ in $0.01 \mathrm{M}$ PBST. Finally, sections were detected by DAB staining. Negative control was performed by replacing the primary antibody with $2 \%$ goat serum to ascertain the specificity of antibody staining. IR products were observed and photographed with a light microscope (Leica. DMIRB, Germany) coupled with a computer assisted video camera.

\section{Competing interests}

This work is supported by National Natural Science Foundation of China. NO. 81100911.

\section{Authors' contributions}

All authors have materially participated in the research and article preparation. Individual contribution to the article of each author is described as follow. YBX, LFZ and THW participated in the planning, execution, analysis of this study and manuscript preparation. FW, BJQ, LY and BTL were in charge of transgenic mice breeding and genotype detections. WZ, XZQ and WPG carried out animal generation. SL revised the manuscript. All authors read and approved the final manuscript.

\section{Author details}

${ }^{1}$ Institute of Neuroscience, Kunming Medical University, 1168 West Chunrong Road, Yuhua Avenue, Chenggong District, Kunming 650500, Yunnan, China. ${ }^{2}$ Institute of Neurological Disease, Transformational Neuroscience Centre, West China Hospital, Sichuan University, NO. 17 Renmin South Road, Chengdu 610041, China. ${ }^{3}$ Key Laboratory of Human Diseases Comparative Medicine, Ministry of Health, Chinese Academy of Medical Sciences (CAMS) \& Comparative Medicine Centre, Peking Union Medical College (PUMC), NO. 5 Panjiayuan Nanli, Beijing 100021, China. ${ }^{4}$ Institute of Laboratory Animal Science, Chinese Academy of Medical Sciences (CAMS) \& Comparative Medicine Centre, Peking Union Medical College (PUMC), NO. 5 Panjiayuan Nanli, Beijing 100021, China. 
Received: 11 September 2012 Accepted: 27 July 2013

Published: 6 August 2013

\section{References}

1. Fawcett JW, Asher RA: The glial scar and central nervous system repair. Brain Res Bull 1999, 49:377-391.

2. Beynon A: Spinal cord injuries. Nurs Stand 2011, 25:59.

3. McCall J, Weidner N, Blesch A: Neurotrophic factors in combinatorial approaches for spinal cord regeneration. Cell Tissue Res 2012, 349:27-37.

4. Koda M, Hashimoto M, Murakami M, Yoshinaga K, Ikeda O, Yamazaki M: Adenovirus vector-mediated in vivo gene transfer of brain-derived neurotrophic factor (BDNF) promotes rubrospinal axonal regeneration and functional recovery after complete transection of the adult rat spinal cord. J Neurotrauma 2004, 21:329-337.

5. Tang XQ, Wang Y, Huang ZH, Han JS, Wan Y: Adenovirus-mediated delivery of GDNF ameliorates corticospinal neuronal atrophy and motor function deficits in rats with spinal cord injury. Neuroreport 2004, 15:425-429.

6. Ruitenberg MJ, Blits B, Dijkhuizen PA, te Beek ET, Bakker A, van Heerikhuize JJ, Pool CW, Hermens WT, Boer GJ, Verhaagen J: Adeno-associated viral vector- mediated gene transfer of brain-derived neurotrophic factor reverses atrophy of rubrospinal neurons following both acute and chronic spinal cord injury. Neurobiol Dis 2004, 15:394-406.

7. Noguti T, Adachi-Yamada T, Katagiri T, Kawakami A, Iwami M, Ishibashi J, Kataoka H, Suzuki A, Go M, Ishizaki H: Insect prothoracicotropic hormone: a new member of the vertebrate growth factor superfamily. FEBS Lett 1995, 376:251-256.

8. Dobbertin A, Schmid P, Gelman M, Glowinski J, Mallat M: Neurons promote macrophage proliferation by producing transforming growth factorbeta2. J Neurosci 1997, 17:5305-5315.

9. Massague J: TGF-beta signal transduction. Annu Rev Biochem 1998, 67:753-791.

10. Massague J, Blain SW, Lo RS: TGFbeta signaling in growth control, cancer, and heritable disorders. Cell 2000, 103:295-309.

11. Anjaneyulu M, Berent-Spillson A, Inoue T, Choi J, Cherian K, Russell JW: Transforming growth factor-beta induces cellular injury in experimental diabetic neuropathy. Exp Neurol 2008, 211:469-479.

12. Saika S: TGF-beta signal transduction in corneal wound healing as a therapeutic target. Cornea 2004, 23:S25-S30.

13. Zhang L, Wang W, Hayashi Y, Jester JV, Birk DE, Gao M, Liu CY, Kao WW, Karin M, Xia Y: A role for MEK kinase 1 in TGF-beta/activin-induced epithelium movement and embryonic eyelid closure. EMBO J 2003, 22:4443-4454.

14. Krieglstein K, Richter S, Farkas L, Schuster N, Dünker N, Oppenheim RW, Unsicker K: Reduction of endogenous transforming growth factors beta prevents ontogenetic neuron death. Nat Neurosci 2000, 3:1085-1090.

15. Carrington LM, Albon J, Anderson I, Kamma C, Boulton M: Differential regulation of key stages in early corneal wound healing by TGF-beta isoforms and their inhibitors. Invest Ophthalmol Vis Sci 2006, 47:1886-1894.

16. Buss A, Pech K, Kakulas BA, Martin D, Schoenen J, Noth J, Brook GA: TGFbeta1 and TGF-beta2 expression after traumatic human spinal cord injury. Spinal Cord 2008, 46:364-371.

17. Sanford LP, Ormsby I, Gittenberger-de Groot AC, Sariola H, Friedman R, Boivin GP, Cardell EL, Doetschman T: TGFbeta2 knockout mice have multiple developmental defects that are non-overlapping with other TGFbeta knockout phenotypes. Development 1997, 124:2659-2670.

18. Hinshelwood RA, Huschtscha LI, Melki J, Stirzaker C, Abdipranoto A, Vissel B, Ravasi T, Wells CA, Hume DA, Reddel RR, Clark SJ: Concordant epigenetic silencing of transforming growth factor-beta signaling pathway genes occurs early in breast carcinogenesis. Cancer Res 2007, 67:11517-11527.

19. Flanders KC, Ren RF, Lippa CF: Transforming growth factor-betas in neurodegenerative disease. Prog Neurobiol 1998, 54:71-85.

20. Lippa CF, Smith TW, Flanders KC: Transforming growth factor-beta: neuronal and glial expression in CNS degenerative diseases. Neurodegeneration 1995, 4:425-432.

21. De Groot CJ, Montagne L, Barten AD, Sminia P, Van Der Valk P: Expression of transforming growth factor (TGF)-beta1, -beta2, and -beta3 isoforms and TGF-beta type I and type II receptors in multiple sclerosis lesions and human adult astrocyte cultures. J Neuropathol Exp Neurol 1999, 58:174-187.
22. Lagord C, Berry M, Logan A: Expression of TGFbeta2 but not TGFbeta1 correlates with the deposition of scar tissue in the lesioned spinal cord. Mol Cell Neurosci 2002, 20:69-92.

23. Peress NS, Perillo E: Differential expression of TGF-beta 1, 2 and 3 isotypes in Alzheimer's disease: a comparative immunohistochemical study with cerebral infarction, aged human and mouse control brains. J Neuropathol Exp Neurol 1995, 54:802-811.

24. De Crescenzo G, Grothe S, Zwaagstra J, Tsang M, O'Connor-McCourt MD: Real-time monitoring of the interactions of transforming growth factorbeta (TGF-beta) isoforms with latency-associated protein and the ectodomains of the TGF-beta type II and III receptors reveals different kinetic models and stoichiometries of binding. $J$ Biol Chem 2001, 276:29632-29643.

25. Goumans MJ, Mummery C: Functional analysis of the TGFbeta receptor/ Smad pathway through gene ablation in mice. Int J Dev Biol 2000, 44:253-265.

26. Lu L, Saulis AS, Liu WR, Roy NK, Chao JD, Ledbetter S, Mustoe TA: The temporal effects of anti-TGF-beta1, 2, and 3 monoclonal antibody on wound healing and hypertrophic scar formation. J Am Coll Surg 2005, 201:391-397.

27. Shull MM, Ormsby I, Kier AB, Pawlowski S, Diebold RJ, Yin M, Allen R Sidman C, Proetzel G, Calvin D: Targeted disruption of the mouse transforming growth factor-beta 1 gene results in multifocal inflammatory disease. Nature 1992, 359:693-699.

28. Kulkarni AB, Huh CG, Becker D, Geiser A, Lyght M, Flanders KC, Roberts AB, Sporn MB, Ward JM, Karlsson S: Transforming growth factor beta 1 null mutation in mice causes excessive inflammatory response and early death. Proc Natl Acad Sci USA 1993, 90:770-774.

doi:10.1186/1471-2091-14-21

Cite this article as: XiYang et al: Newly developed TGF- $\beta 2$ knock down transgenic mouse lines express TGF- $\beta 2$ differently and its distribution in multiple tissues varies. BMC Biochemistry 2013 14:21.

\section{Submit your next manuscript to BioMed Central and take full advantage of:}

- Convenient online submission

- Thorough peer review

- No space constraints or color figure charges

- Immediate publication on acceptance

- Inclusion in PubMed, CAS, Scopus and Google Scholar

- Research which is freely available for redistribution 